as 'bean', 'bund', 'Christmas tree', 'feedstock', 'fishing', 'go-devil', 'overhead', 'packer', 'sweating', 'wildeat', to quote only a few, have quite different meanings in this industry from those ordinarily understood in general conversation. There is need for such specialized guidance as this, especially for the non-technical people in the industry, but this diminutive pamphlet (it is scarcely more than that, for of its 39 pages, 29 are devoted to the 'glossary' itself, 7 to an appendix on petroleum terms in U.K. legislation, 3 to abbreviations of titles of some official bodies, for example, API, DTD, IP, NCB, SAE, etc.) provides only modest fulfilment. Petroleum technology to-day is such an enormously ramified subject that nothing short of a comprehensive dictionary devoted to its tenets can cover the ground of its words and meanings adequately. The task has been attempted elsewhere some years ago, but even then on a rather limited scale. Whether the time is now ripe for conception and execution of a bold enterprise of this nature is a matter of judgement, policy and cost, but it is one to which the Institute of Petroleum, responsible for this Glossary, might well give careful consideration before the next edition is due for publication.

\section{Improving Biological Communications in the United States}

Establishment of a Biological Serials Record Centre is a principal recommendation of the Biological Communications Project, supported by the National Science Foundation, with the objective of collecting and disseminating detailed information on all biological serial and periodical publications, estimated at 25,000-50,000. The Centre will assess what proportion of this material is available to biologists in the United States, and will also study the general effectiveness of present periodicals as a system of communication. The National Science Foundation has also made a grant of 56,000 dollars for a one-year study of chemical notation systems, to be conducted by the National Academy of SciencesNational Research Council, and is supporting for a second year the Chemical Abstracts Service of the American Chemical Society's project to provide a centralized information service for chemists. A survey of computer systems for searching chemical literature has been completed by the National Bureau of Standards Research Information Centre and Advisory Service on Information Processing, and its results are available in a report by E. C. Medam and H. R. Koller, obtainable at 2.25 dollars from the Office of Technical Services, U.S. Department of Commerce, Washington 25, D.C.

\section{Eoliths and Prehistorical Tools}

As far back as 1911 there were furious quarrels among British prehistorians as to whether or not the Tertiary eoliths found by Reid Moir were really fashioned by man. To some extent the quarrel was theological: Was it conceivable that mankind could be as old as was suggested by the finds? Much research was undertaken, and at the time it was determined that Nature could chip, the blows coming from one or many directions, but not from two, or, better, three directions only. Further, if a piece of tabular flint was boldly chipped along one edge and then the aretes between the flake scars carefully removed by subsequent flaking so as to produce a sharp, flaked edge, then Nature could not have been responsible for the work. Briefly, if it were possible to demonstrate design then the chipped object had been fashioned by man. Later the study of prehistory spread to other continents, but the above criteria were largely forgotten. Much chipped material claimed to be man's handiwork was unearthed and this material in turn became the yardstick for the study of still more flaked objects. Now the matter is being carefully reconsidered, and Dr. Desmond Clark has undertaken considerable research work, especially as regards materials other than flint. In a recent monograph (Bull. Brit. Mus. (Nat. Hist.), 5, No. 4. Pp. 71-90 + plates 15-23. London: British Museum (Natural History). 17s. 6d.), Dr. Clark concerns himself with specimens of very early Pleistocene age from certain beds in Israel. His conclusions are that probably every one of the specimens in question has been flaked by natural agencies, and these agencies he describes in some detail. Of course, should man have been in existence at the time in what is now Israel there was nothing to stop him picking up a naturally chipped object and using it as a tool. But that is not the question under consideration. The article has a wider interest than merely whether certain specimens from Israel were fashioned by Nature or by man; the detailed studies of how Nature can work will be very useful to prehistorians in other areas when they have to determine whether or not their early finds are really genuine tools or lusi naturae.

\section{The Institute of Fuel}

Dr. JAmes BURNS, deputy chairman, North Thames Gas Board, has been elected president of the Institute of Fuel, and will take office in October. Sir Harold Hartley has been made an honorary member of the Institute. Sir Harold was chairman of the Fuel Research Board of the Department of Scientific and Industrial Research during 1932-47; chairman of the British National Committee and of the International Executive Council of the World Power Conference during 1935-50; and president of the Conference during 1950-56.

\section{Commonwealth Scientific and Industrial Research Organization Chemical Research Laboratories}

Following the appointment of the director of the Commonwealth Scientific and Industrial Research Organization Chemical Research Laboratories, Dr. I. W. Wark, to the Executive, it has been decided that, in future, overall management of these Laboratories will be the responsibility of a committee of the chiefs and officers-in-charge of the various divisions and sections at Fishermen's Bend, Melbourne. The first chairman is Dr. A. L. G. Rees, chief of the Chemical Physics Division.

\section{A New Computing Centre}

ON June 7 the IBM Co. opened a new dataprocessing centre at 58 Newman Street, London. This centre is equipped with type 7090 and type 1401 computers; the former machine is one of the most powerful at present in operation, and the latter forms a suitable second echelon support device. Users of the centre are expected to do their own programming, but this is relatively easy because the Fortran automatic programming system is available and this is backed by the Share user co-operation system. The centre staff will be available for basic training and also to give advice to users in particular cases. 